\title{
Applying of Hypertext to Promote EFL Students' Reading Comprehension
}

\author{
Tatu Munawaroh ${ }^{1}$
}

${ }^{1}$ English Education Study Program of Teacher Training and Education Faculty, Universitas Mathla'ul Anwar Banten

ARTICLE INFO

Keywords:

Reading

Comprehension

Hypertext

\begin{abstract}
This study investigated applying of hypertext to promote EFL for students to improve reading comprehension. The objective of this study is to find out the implementation of hypertext and to what extent the use of hypertext can improve students' reading comprehension. This study is applying classroom action research which was conducted at one of senior high school in Pandeglang and predicated by 27 second grade students of senior high school. For analysis of the data, this study used qualitative approach supported with observation, students' test, questionnaire, and interview. This study showed applying of hypertext in teaching and learning process was successful. The data gained from students' test showed that the applying of hypertext to promote EFL can improve students' reading comprehension. The mean of students score in the third cycle was 73.92 with twenty one students achieved score above minimum completion score or KKM (70). In addition, most students agree that applying of hypertext can improve their reading comprehension. For the finding it is recommended for further studies that the applying of hypertext can be implemented in teaching English lesson to improve the students' reading comprehension.
\end{abstract}

This is an open access article distributed under the terms of the Creative Commons Attribution 4.0 International License, which permits unrestricted use, distribution, and reproduction in any medium, provided the original work is properly cited. @ 2019 Tatu Munawaroh

\section{INTRODUCTION}

Since English becomes an international language, the needs of mastering it become more significant. As many things involving English, everyone tries to learn it especially for the needs of global communication. Therefore, English becomes crucial to communicate in many parties, like business, education, politic, social relationship and many other aspects. In some countries in which English is considered as a foreign language, it is a bit difficult for students to master English well. One of the problems faced by the students is reading comprehension. In capable in English, students have to able to master four skills of English namely listening, speaking, reading and writing. Reading is one of the four skills: reading, writing, listening and speaking. It is receptive skill, like listening that involves responding text, rather producing it. Very simply we can say that reading involves making sense of text. To do this we need to understand the language of the text at word level, sentence level and whole-text level. We also need to connect the massage of the text to our knowledge of the world.

${ }^{1}$ Corresponding author's address: English Education Study Program of Teacher Training and Education Faculty, Universitas Mathla'ul Anwar, Banten, Indonesia e-mail: tatumunawaroh92@gmail.com 
In Indonesia, English is a compulsory subject in every education level from senior high school to university level. In addition, English language is included as local content subject in education level of elementary school in the country. The teaching process in education levels is based on the guideline of rules that stated by the government in the curriculum. Based on the recent curriculum of senior high school, as stated in Permendikbud No. 81A in 2013 about Curriculum, implementation and the implementation of 2013 Curriculum, students of senior high school are expected to be able to understand the purpose, text structure, and language elements of the written descriptive texts about people, animal, and things, very short and simple story. Students also expected to master kinds of reading text namely descriptive, recount and narrative.

However in the reality, there are still many students whose English reading score are still low. The teacher said that most of students still have reading problems, such as difficulty to understand the texts, lack of vocabulary, and low speed of reading. It seems that students' difficulty in reading was caused by the source of the reading text was to long so students boring with text. It can be seen by investigating directly on daily the students' activities, students' reading activities and the result of their reading test. Some of students were rarely to read either extensive reading or intensive reading. Besides, the students at senior high school the scores in reading and the average of students test is 60. Referring to (Kriteria Ketuntasan Minimal/KKM) score was 75 (curriculum 2013), it can be stated that the score is lower than the KKM.

In reading process, every student frequently finds problems in understanding a long text. Once they notice the text with long sentences, words with long syllables, and many paragraphs, the reading process becomes uninteresting and it can cause the decrease of the student motivation in learning. It gives impact on their comprehension of the text. Therefore, in learning hypertext proved able to improve English language in reading comprehension.

In solving students' problems on reading, this is crucial components that have to be improved in the teaching and learning descriptive text. Applying hypertext as media is good way. Hypertext is one of media can helps the teachers in teaching and learning which describe "non-sequential documents" composed of text, audio, and visual information stored in computer, with the computer being used to link and annotate related chunks of information (nodes) into larger networks or webs. And then, students also need a material that is simple, easy, authentic, educational, interested, motivated, and enjoyable to learn reading comprehension of descriptive text. Applying hypertext can give impact to promote EFL in developing students' reading comprehension. Hypertext offers the great benefit to students for create teaching and learning English easy, interesting and fun. One of the advantages of applying hypertext to learn English as a means for stimulate students in order to be familiar with the new word. This is particularly media can help student enhance their reading comprehension in descriptive text. Hypertext as a media facilitate teachers create particular context where language is most meaningful and useful.

According to Heinich, Molenda, Russel and Smaldino (2002, p. 244) the term hypertext was coined by Nelson to describe "nonsequential documents" composed of text, audio, and visual information stored in computer, with the computer being used to link and annotate related chunks of information (nodes) into larger networks or webs.

From the statement above, it is concluded that hypertext was a text that was not sequential provided in computer with the help of the link that contains texts. Every school in this way was not often used and students generally got text with monotonous learning. To attract students in reading is need of new effective way of teaching because here not only text but also introduced voice and images which allow using it in its own ways and the way this is called hypertext. Therefore, by using hypertext education activities in the teaching can be more creative.

Shneiderman and Kearsley (2009, p.3-4) said that the most common meaning of "Hypertext" was a data base that has active cross references and allows the reader to "jump" to other parts of the 
database as desired. This makes the reading (and writing) process non sequential. It was the requirement for active cross-references that makes a computer necessary to implement Hypertext.

From the statement above, hypertext was a system that has liveliness between references and allows the reader to jump or move on to another section. Here it is said that the reading process was not sequential because, in general, when the reader opens the computer that as connected by a link and then open a document, so reference liveliness is that happened when students read. The possibility that once the reader opened the document and the next contained new vocabulary or sentence that the reader may not know what the meaning of the sentence, it automatically jump from the reader to the original text and the new text as was later when the new text reader difficult to find words and the reader click the word it automatically be assigned to the new switch readers.

Linse (2005:71) Reading comprehension refers to reading for meaning, understanding and entertainment. Reading comprehension involves higher-order thinking skills and much more complex that merely decoding specific words. Teaching students how to derive meaning as well as analyze and synthesize what they have read is an essential part of the reading process.

Reading comprehension was strategies readers used to retrieve information and construct meaning from the text. They were the linking processes, broken down into steps that are used to comprehend. These must be taught explicitly. Three types of comprehension skill were described below: pre-reading, during-reading, and post-reading. These comprehension skills can be easily learned and flexibly applied to a variety of reading situations (Johnson, 2008, p.110).

Reading comprehension was one of the pillars of the act of reading. When a person reads a text he engages in a complex array of cognitive processes. He was simultaneously using his awareness and understanding of phonemes (individual sound "pieces" in language), phonics, (connection between letters and sounds and the relationship between sounds, letters and words) and ability to comprehend or construct meaning from the text. This last component of the act of reading was reading comprehension. It cannot occur independent of the other two elements of the process. At the same time, it was the most difficult and most important of the three.

From the definition above, that reading comprehension was the process of understanding the ideas and information that the text's researcher or author wants to express which depends on the information provided in the text. In this research, the researcher took intensive reading assessment in the form of multiple choices.

\section{METHOD}

The research has been conducted at at SMK WAlisongo located on Jalan Raya Labuan Km.11, Menes, Pandeglang Regency, Banten province. This research would be conduct about one month in the first semester 2017/2018 academic years, from August up to September. This research was conducted qualitatively using action research. Since this research attempted to explore the using of hypertext to promote EFL to learn English text, it employed the qualitative research design with the characteristics of action research. Action researches choose because this research aims to identify a situation or issue that subjects considered worth looking into more deeply and systematically. McNiff with Whitehead (2002, p.15) stated, "Because action research was always to do with learning, and learning was to do with education and growth, many people regard it as a form of educational research."

Action research involves participant in planning action (on the basis of reflection); in implementing these plans in their own action; in observing systematically this process; and in evaluating their action in the light of evidence as a basis for further planning and action, and so son through a self-reflection spiral. 


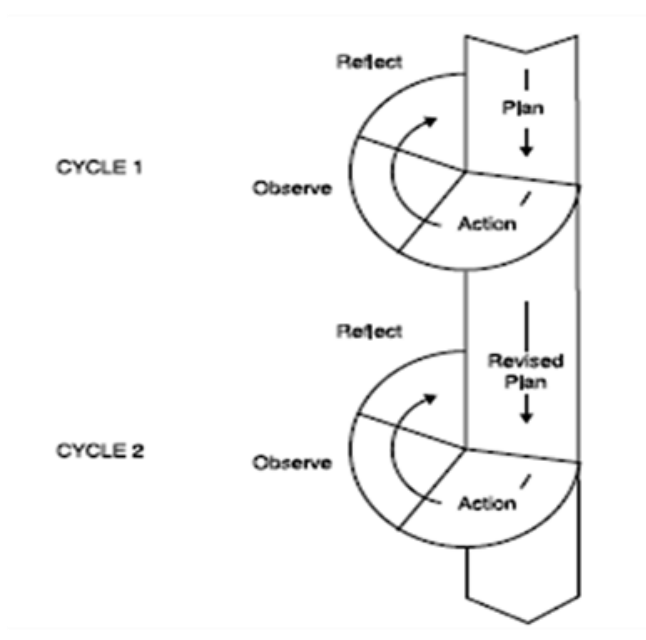

Figure 1. Classroom action research stages

As shown by the Figure, action research process consists of four steps, namely planning, action, observation, and reflection. Each step has different activities. According to Woodbury (2002:06) states "the population is a collection of people, objects, or measurements that we are interested in analyzing." the population of this research is 27 students from the first grade of SMK Walisongo Menes.

In this study, the research used qualitative research by using multiple techniques of the data collection technique. They were test, interview, and observation. The kinds of field notes used to record the teaching learning process in the classroom. The researcher made some notes related to the situation that can be notice during the teaching learning process. From the field notes, the researcher found the problems and weaknesses of the actions. Besides, the researcher also saw the students $^{\text {ee }}$ progress in every meeting.

\section{DISCUSSION}

After implementing applying hypertext to promote EFL students' reading comprehension the researcher got the data from each cycle. Then, the data were analyzed to find out whether there was improvement in every cycle. This is the results as follows:

Table 1. The results of students' score mean and the percentage of the students who passed the target score from pre-test until post-test

\begin{tabular}{lcccccc}
\hline No & Name of Students & Pre Test & Test 1 & Test 2 & Test & Post Test \\
\hline 1. & RPLS1 & 52 & 60 & 76 & 80 & 84 \\
\hline 2. & RPLS2 & 48 & 56 & 64 & 76 & 80 \\
\hline 3. & RPLS3 & 64 & 72 & 72 & 80 & 80 \\
\hline 4. & RPLS4 & 56 & 56 & 60 & 80 & 80 \\
\hline 5. & RPLS5 & 52 & 60 & 72 & 76 & 84 \\
\hline 6. & RPLS6 & 56 & 64 & 68 & 68 & 62 \\
\hline 7. & RPLS7 & 64 & 64 & 80 & 80 & 80 \\
\hline 8. & RPLS8 & 72 & 76 & 72 & 76 & 80 \\
\hline 9. & RPLS9 & 76 & 76 & 80 & 80 & 72 \\
\hline 10. & RPLS10 & 48 & 52 & 68 & 76 & 76 \\
\hline 11. & RPLS11 & 44 & 56 & 72 & 76 & 76 \\
\hline 12. & RPLS12 & 56 & 52 & 56 & 62 & 76 \\
\hline 13. & RPLS13 & 56 & 56 & 60 & 68 & 76 \\
\hline 14. & RPLS14 & 44 & 60 & 68 & 76 & 72 \\
\hline 15. & RPLS15 & 60 & 72 & 72 & 80 & 88 \\
\hline 16. & RPLS16 & 68 & 76 & 72 & 76 & 76 \\
\hline
\end{tabular}




\begin{tabular}{lcccccc}
\hline 17. & RPLS17 & 72 & 72 & 80 & 76 & 80 \\
\hline 18. & RPLS18 & 48 & 56 & 72 & 72 & 72 \\
\hline 19. & RPLS19 & 44 & 52 & 56 & 64 & 68 \\
\hline 20. & RPLS20 & 48 & 56 & 72 & 76 & 80 \\
\hline 21. & RPLS21 & 44 & 52 & 60 & 64 & 64 \\
\hline 22. & RPLS22 & 52 & 56 & 72 & 72 & 72 \\
\hline 23. & RPLS23 & 64 & 64 & 72 & 76 & 76 \\
\hline 24. & RPLS24 & 52 & 52 & 60 & 76 & 80 \\
\hline 25. & RPLS25 & 48 & 48 & 56 & 60 & 68 \\
\hline 26. & RPLS26 & 60 & 56 & 60 & 72 & 68 \\
\hline 27. & RPLS27 & 72 & 72 & 80 & 78 & 80 \\
\hline & Total & $\mathbf{1 5 2 0}$ & $\mathbf{1 6 4 4}$ & $\mathbf{1 8 4 8}$ & $\mathbf{1 9 9 6}$ & $\mathbf{2 0 5 0}$ \\
\hline & Average & $\mathbf{5 6 . 2 9}$ & $\mathbf{6 0 . 8 8}$ & $\mathbf{6 8 . 4 4}$ & $\mathbf{7 3 . 9 2}$ & $\mathbf{7 5 . 9 2}$ \\
\hline & $\mathbf{P}$ & $\mathbf{1 4 . 8 1 \%}$ & $\mathbf{2 5 . 9 2 \%}$ & $\mathbf{5 5 . 5 5 \%}$ & $\mathbf{7 7 . 7 7 \%}$ & $\mathbf{8 1 . 4 8 \%}$ \\
\hline
\end{tabular}

Based on the table above, there was improvement from the pre-test until the post-test. The mean of the students' score and the percentage of the students who passed the target score improved well and even finally met the target of the research. So, it can be concluded that the using of hypertext was able to improve the students' reading comprehension. Besides, the data also showed that this classroom action research was successful because it had fulfilled the criteria of success.

In this researcher would like to answer the questions in the formulation of the problems by using the research findings above. The details were explained as follows:

\section{The Using of Hypertext in Improving Students' Reading Comprehension}

According to Heinich, Molenda, Russel and Smaldino (2002, p. 244) the term hypertext was coined by Nelson to describe "non-sequential documents" composed of text, audio, and visual information stored in computer, with the computer being used to link and annotate related chunks of information (nodes) into larger networks or webs. In this research, researcher found the students were not able to identify common images, specific and detailed information of descriptive text about the sights with confidence and responsibility still hard to read in English text namely descriptive text. It is because they was not mastering on vocabularies and automatically they need opened dictionary so, limited time on answered questions.

Based on researcher's finding, the researcher used hypertext as a solution. Supported by Nielsen (2005, p.1-2), The Used of Hypertext in Teaching Reading Comprehension can help by links were usually denoted by words or phrases that were highlighted in some fashion, but they can also be graphics or icons. For example, each component of a schematic diagram may be a link to a more detailed schematic of that component or to a text description. Links can produce a variety of different results. They can:

a. transfer to a new topic

b. show a reference (or go from a reference to the article)

c. provide ancillary information, such as a footnote, definition, or annotation

d. display an illustration, schematic, photograph, or video sequence

e. display an index

f. run another program (e.g., a spreadsheet or animation)

The previous studies that had been conducted to analyze the used of hypertext in teaching English by Abdi (2012) who investigated theeffectiveness of using hypertext materials on reading comprehension ability on learners as compared to the normality written material. This studies used quantitative design with total populations were 49 male and female students and sampling of experiment are 24 students and then at control were 25 students. In this study, he used two 
treatments of the experimental group was given by hypertext material and the control group was given by written material.

The findings indicated that participants in the experimental group assumed more gain in reading comprehension ability as a result of working with hypertext materials as compared to non-digital material. It is same that the result of the study showed that hypertext gave good effect to improve students' reading comprehension. Based on statement above, the using of hypertext can improve students' reading comprehension. It is show the result of the tests from pretest until post-test to answer this question. Based on table 1 above, the mean of the students" score from pre-test until post-test was improved. In the post-test, the mean of the students" score was 75.92 and it was higher than the target of the research which was 70. The improvement of the mean of the students" score, table 4.6 also showed the improvement of the percentage of the students who passed the target score. In the pre-test, there were only $14.81 \%$ of the students who passed the target score. The percentage was improved significantly after the students were treated by using hypertext. It could be seen from the table that showed the percentage of the students who passed the target score was $81.48 \%$. The percentage of the students who passed the target score in the post-test was higher than the research target which was $75 \%$. So, the using of hypertext was able to improve the students" reading comprehension.

\section{The Problems Faced by the Teacher in Improving Students' Reading Comprehension}

To answer this question, the researcher used interview and field note. Based on the interview and field note, there were some obstacles which faced 90 by the students in learning reading comprehension by using hypertext. The first obstacle he used usual method in understands and answers the texts. He said that taught by hypertext was new method for him. It could be seen from the following transcripts:

"Permasalahan yang kerap saya temui adalah kurangnya pembendaharaan akan kosakata mereka dan mereka kerap membandingkan penguasaan kosakata dengan kehidupan sehari-hari".

(I was found that Student's problems in reading compere are less of their vocabularies of English, and useless in daily life) question's code 1

"Mengatasi dan memberikan solusi kepada siswa, ketika mereka punya malasah dalam penggunaan bahasa inggris dan tugas bahasa inggris saya memberikan kosakata baru serta memberitau bagaimana cara pengucapan sampai mereka lancar".

(And to overcome and give solution for students, when students have problems in English used and mastering vocabularies, I gave new vocabularies and how to spell and say, until they can say that fluency) question's code 2

"Kesulitan di dalam meningkatkan pemahaman membaca siswa adalah kecenderungan di dalam bahasa inggris, karena lingkungan dan keluarga mereka yang tidak menggunakan bahasa inggris".

(The problem and difficulties in improving student's reading comprehension is their proclivity in English, because of their environment and family life in using English) question's code 3

"Hypertext adalah metode baru yang di gunakan untuk meningkatkan pemahaman membaca yang menggunakan jaringan computer".

(Hypertext is new method that used to improve understanding of reading students who use computers network) question's code 4

"Saya rasa hypertext sangat efektif. Ini adalah cara baru di dalam pengajaran membaca selain itu di sini juga bisa mengelaborasikan di dalam memberikan kosakata dan meningkatkan motivasi siswa di dalam membaca. Sehingga pada permasalahan ini siswa bisa mengerti dan tau maksud dari teks sampai pada menjawab soal". 
(I think hypertext very effective. This is a new method of reading teaching besides that here also can elaborate between teaching vocabulary and improving students' motivation in reading English. So, that on this students problems they can understand and know the mean of the texts until answering the question) question's code 5

One previous study was conducted by Konishi (2003) who investigated what kinds of strategies ESL learners used when they read through the authentic Web pages on the Internet. The population of this research is the students of a major university in Melbourne, Australia. The samples were only six students. The data included the transcribed videotapes of each participant"s think-aloud protocol; the behaviors of the participants during the think aloud session; recorded screens of the computer each participant operated with during the think aloud session; the results of tracking; and the responses to the background questionnaire and to the interview. The result of the study showed that hypertext in various strategies was able to improve not only students' reading skill but also their motivation. It is same research that the research was not focus on students reading but also their motivation.

Based on the interview transcripts and the statement above, it could be concluded that the students felt difficult to mastery of vocabulary especially unfamiliar words. The difficulty in memorizing the vocabulary was faced not only by the students who learnt it for the first time but also the students who had learnt it before. So, the students needed more practice to be familiar with the words. And then the hypertext can gave solution on these problems.

\section{The Students' Responses in Using of Hypertext to Promote EFL Students' Reading Comprehension}

Johnson (2008, p.5) stated: "During the act of reading, the visual information found on the page combines with the non-visual information contained in our head to create meaning." In that way, what"s in your head was just as important as what was on the page in the process of creating meaning (reading). The researcher found on the interview and field note, there were some obstacles which faced by the students in learning reading comprehension by using hypertext. The first obstacle was the difficulty in understand and answer the texts. The students said that it was a bit difficult to understand a text especially in unfamiliar words. It could be seen from the following transcripts:

"Saya kurang faham dengan pengaplikasian komputer. Teks pada komputer membuat saya bingung harus bagaimana dan apa yang harus saya jawab sebab lagi-lagi saya terkendala pada kosakata, Miss, ini karena baru pertama kalinya belajar membaca dengan menggunakan hypertext, Miss".

(I did not understand how to use hypertext, the text on computer screen made me confused about how and I should do. Because I have problems with vocabularies Miss, It is because this is the first time for me to learn it,) Student's code: RPLS17

"Wah kalo itu sich masalah nya susah dalam penguasaan kosakata dan terkendala pada koneksi jaringan, Miss. Padahal sebelumnya saya juga sudah pernah belajar membaca bahasa inggris, tapi tetap aja susah Miss jawabnya."

(My problem is the difficulty to mastery of vocabulary and trouble with connection of computer. Whereas I had learnt reading English text in my previous college, but it is still difficult for me to memorize them.) Student's code: RPLS27

The previous study was conducted by Lopez (2006) who explored students" EFL writing through hypertext design. This research was a qualitative case study which was done to explore and document how students deal with grammatical, textual and pragmatic aspects when writing hypertext. The results were process of collaborative hypertext writing and negation and the used of concept mapping and other strategies to overcome difficulties in hypertext writing. It is different with I research, because he explored students" EFL writing and I explored students" 
reading comprehension. But here got good result because hypertext can gave positive effect and then gave improvement on the research.

Based on the interview transcripts and statement above, it could be concluded that on the observation which was written in the field note, some students still consulted their reading comprehension to know the language feature which was represented by the tenses that was difficult for them to memorize. This obstacle was considered as common obstacle because learning hypertext was still a new experience for them. So, in these problems the students needed more practice. And then the hypertext can gave solution on these problems.

\section{CONCLUSION}

According to Heinich, Molenda, Russel and Smaldino (2002, p. 244) the term hypertext was coined by Nelson to describe "non-sequential documents" composed of text, audio, and visual information stored in computer, with the computer being used to link and annotate related chunks of information (nodes) into larger networks or webs.

In this research, researcher found the students were not able to identify common images, specific and detailed information of descriptive text about the sights with confidence and responsibility still hard to read in English text namely descriptive text. It is because they was not mastering on vocabularies and limited of motivation so automatically they need opened dictionary and limited time on answered questions.

However, the researcher also found the problems which were faced by the students during the implementation of the using of hypertext to promote EFL. The first problem was the students were difficult in understand the text. It was experienced by not only the students who learnt the language feature for the first time but also those who had learnt the word before. So, the students needed more practice to be familiar with the word.

Based on researchers' found, the researcher used hypertext as a solution. Supported by Nielsen (2005, p.1-2), The Used of Hypertext in Teaching Reading Comprehension can help by links were usually denoted by words or phrases that were highlighted in some fashion, but they can also be graphics or icons. For example, each component of a schematic diagram may be a link to a more detailed schematic of that component or to a text description. Links can produce a variety of different results. They can:

a. transfer to a new topic

b. show a reference (or go from a reference to the article)

c. provide ancillary information, such as a footnote, definition, or annotation

d. display an illustration, schematic, photograph, or video sequence

e. display an index

f. run another program (e.g., a spreadsheet or animation)

Based on the research finding and discussion, the researcher concluded that the using of hypertext to promote EFL improve students' reading comprehension was successful. It could be seen from table 4.6 that showed the improvement of students' score mean and the percentage of the students who passed the target score from pre-test until post-test and the finding of result supported by Heinich, Molenda, Russel and Smaldino (2002, p.244), the goal of Hypertext was to immerse users in a richly textured information environment, one in which words, sounds, and still and motion images can be connected in diverse ways. Enthusiasts feel that the characteristics of hypertext parallel the associative properties of the mind, thereby making the construction of one's own web a creative education activity.

Based on the research findings, the researcher would like to propose some suggestions that would hopefully be useful for the English teachers, the institutions, and other researchers. The first for teacher, the teachers should enhance their ability in teaching English and develop a good atmosphere in the class to make students more comfortable during teaching and learning process. 
It is also necessary for teachers to utilize interesting method and media in teaching English especially teaching reading comprehension. The second for institutions, the institution should encourage and support the English teachers to improve their teaching skills such as providing facilities for the teachers to improve their teaching skills. The last for other researchers, this study discusses the use of the using of hypertext to promote EFL to improve students' reading skill. So, that research engaged in teaching learning process and they will also pay more attention to the teacher's explanation and then the result of the studies can be used as an additional reference for further researches, especially the researches that deal with teaching reading comprehension.

\section{REFERENCES}

Anderson, J, Neil. (2008). Practical English language teaching. New York: McGraw-Hill ESL/ELT.

Abdi, Reza. (2013). The effect of using materials on reading comprehension ability of EFL learners.

Brown, H. D. (2010). Language assessment principles and classroom practice. New York: Pearson Longman.

Burns, A. (2010). Doing action research in English language teaching. New York Routledge.

Brown, H., Douglas. (2007). Teaching by Principle, San Francisco: Longman.

Brown, H, Douglas. (2001). Teaching by Principles: an Interactive Approach to Language Pedagogy. San Francisco: State University.

Bryce, Nadine. (2013). Textual Features and Language Demands of Primary Grade Science Textbooks: The Call for More Informational Texts in Primary Grades. London: Springer.

Castillo and Montoya, M. (2016). Preparing for interview research: The interview protocol refinement. The Qualitative Report.

Dewi, R. (2010). Teaching Reading through Self-Monitoring Approach to Reading and Thinking (smart) Strategy for the eighth grade Students of Junior High School. West Sumatra : STKIP university.

Diaz. B. (2012). The RAP JOURNAL: A National Affiliate of the International Reading Association. Philippines: Reading Association of the Philippines.

Furchan, A. (2004). Pengantar penelitian dalam pendidikan. Yogyakarta: Pustaka Pelajar.

Heinich, R., Molenda, M., Russe, J., \& Smaldino, S. (2002). Instructional Media and Technologies for Learning.

Harmer, J. (1998). How to Teach English. England: Longman.

Heinich, R.., Molenda, M., Russe, J., \& Smaldino, S. (2002). Instructional Media and Technologies for Learning.

Johnson, P, A. (2008). Teaching Reading and Writing.

Konishi, Maesae. (2003). Strategies for reading hypertext by Japanese ESL learners. 